\title{
Pola-Pola Komunitas Situs Gua Kawasan Timur Jawa
}

\section{Indah Asikin Nurani}

Keywords: cave, settlement, spatial, area, pattern, modelling

\section{How to Cite:}

Nurani, I. A. (2001). Pola-Pola Komunitas Situs Gua Kawasan Timur Jawa. Berkala Arkeologi, 21(1), 15-29. https:/ / doi.org/10.30883/jba.v21i1.830

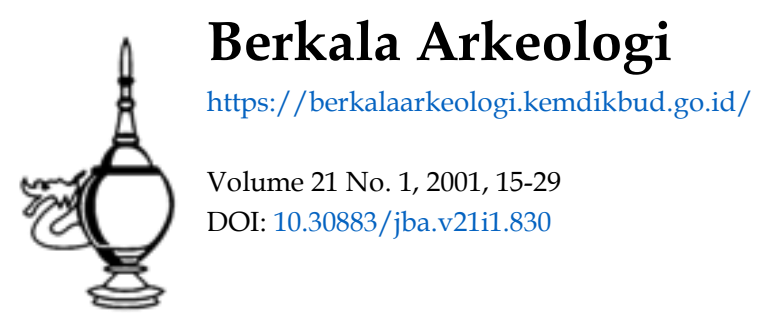

\section{(c) (1) (2)(2)}

This work is licensed under a Creative Commons Attribution-NonCommercial-ShareAlike 4.0 International License. 


\title{
POLA-POLA KOMUNITAS SITUS GUA KAWASAN TIMUR JAWA
}

\author{
Indah Asikin Nurani \\ (Balai Arkeologi Yogyakarta)
}

\section{A. Pendahuluan}

Kehidupan manusia masa prasejarah khususnya kala Plestosen akhir sampai awal Holosen, dalam mempertahankan hidupnya masih sangat bergantung pada sediaan lingkungan alam sekitarnya. Seiring dengan tingkat kecerdasan dan teknologi yang dikenalnya, manusia saat itu lebih mampu mempertahankan hidupnya dan mengeksploitasi alam daripada masa sebelumnya yang masih mengembara. Hal tersebut ditunjukkan dalam pola hidup mereka untuk bertempat tinggal yang lebih menetap dengan memanfaatkan gua atau ceruk sebagai tempat tinggal mereka. Di Asia Tenggara, kehidupan di gua (cave) atau ceruk (rock shelter) mencapai puncaknya pada kala Holosen. Pertimbangan manusia saat itu dalam memanfaatkan gua atau ceruk sebagai tempat tinggal tidak dilakukan secara serampangan. Hal tersebut menunjukkan bahwa tidak semua gua atau ceruk dimanfaatkan sebagai tempat tinggal (tempat bermukim). Dari aspek keletakan, manusia saat itu cenderung memilih lokasi gua atau ceruk pada daerah-daerah yang menyediakan kebutuhan pokoknya, seperti sumber bahan makanan aquatik atau non aquatik yang dianggap menguntungkan dari segi subsistensinya. Sebaliknya mereka tidak akan menempati daerah yang miskin sumber makanan, tandus, penuh bahaya, tidak sehat, atau sulit dari jangkauan baik dalam komunikasi maupun transportasi dari daerah lain. Selain itu, untuk mempertahankan hidupnya, mereka juga membuat perkakas dari bahan yang tersedia di lingkungan sekitarnya seperti dari batu, tulang, tanduk, cangkang moluska, dan kayu. Dengan demikian, sumberdaya lingkungan menentukan corak perkembangan teknologi yang diterapkan dalam pembuatan alat.

Penelitian gua-gua di Jawa khususnya Jawa Timur telah dilakukan oleh beberapa peneliti asing seperti van Es, van Stein Callenfels, Willems, dan H.R. van Heekeren di Kabupaten Ponorogo, Situbondo, Pacitan, Jember, Tuban, dan Bojonegoro. Penelitian tersebut lebih bersifat eksplorasi untuk menjajagi gua-gua hunian di Jawa. Sementara itu, secara tematis yang dititikberatkan pada studi spatial, Balai Arkeologi Yogyakarta telah melakukan penelitian pada kelompok gua di Kabupaten Jember (Gunung Watangan), Kabupaten Bojonegoro (Dander) dan di Kabupaten Ponorogo (Sampung). Sementara itu, penelitian serupa juga telah dilakukan oleh Pusat Penelitian Arkeologi pada kelompok gua di Kab. Gunungkidul sampai Kab. Pacitan (Gunung Sewu).

Berdasarkan penelitian yang telah dilakukan selama ini, tampak bahwa pola permukiman gua memiliki keunikan tersendiri dalam menyiasati cara hidupnya yang 
masih mengandalkan pada potensi ekologis sekitarnya. Hal tersebut menunjukkan bahwa suatu gua akan dimanfaatkan semaksimal mungkin untuk melakukan aktivitasnya, sehingga suatu gua akan memiliki karakteristik tipe aktivitas tertentu. Berangkat dari hal tersebut, menarik untuk dikaji secara mendalam terutama yang berkaitan dengan pengaturan ruang (pola tata ruang mikro) yang diterapkan pada lahan suatu gua yang tersedia dan pengaturan ruang pada tingkat komunitas (pola semi mikro (meso)).

Dalam pemukiman skala mikro kajian didasarkan pada persebaran ruangan dan hubungan antar ruang di dalam satu bangunan, sehingga diketahui struktur sosial (keluarga) yang didasarkan pada hirarki ruang, fungsi ruang, dan gaya bangunan. Selain itu dalam ruang mikro ini dipelajari pula hubungan antara unsur-unsur bangunan dengan komponen-komponen lingkungan alam, untuk mengetahui kearifan lingkungan (strategi adaptif) dalam memanfaatkan sumberdaya alam dan menyesuaikan diri terhadap kondisi lingkungan alam sekitarnya. Dalam tingkat meso (community layout) dipelajari persebaran dan hubungan antar bangunan dengan kondisi lingkungan dan sumberdaya alam. Sedangkan dalam tingkat makro dipelajari persebaran dan hubungan antar situs di dalam satu wilayah, serta persebaran dan hubungan antar situs dengan kondisi lingkungan dan sumberdaya alam (Mundardjito, 1985). Kaitannya dengan gua hunian masa prasejarah ini, istilah bangunan diartikan sebagai sebuah unit ruang hunian. Dengan demikian permukiman tingkat mikro dititikberatkan pada satu gua atau gua payung sebagai tinggalan aktivitas manusia masa prasejarah. Untuk itu dalam mengkaji tingkat keruangan pada suatu permukiman perlu diketahui aktivitas yang berlangsung pada skala terkecil (mikro), sehingga nantinya akan diketahui bagaimana aktivitas skala komunitas (meso) berlangsung.

Berdasarkan uraian tersebut, maka tulisan ini dimaksudkan dapat menjelaskan dua permasalahan yaitu (1) bagaimana pola permukiman skala mikro yang terjadi pada gua/ceruk kawasan timur Jawa? Dan (2) bagaimana pola komunitas yang berlangsung sehubungan dengan penataan gua/ceruk sebagai aktivitas hidupnya?

\section{B. Pola Permukiman Gua-gua di Kawasan Timur Jawa}

Penelitian mengenai kehidupan di gua-gua ataupun ceruk, di Indonesia selama ini telah banyak dilakukan, terutama penelitian yang dilakukan oleh peneliti asing. Berdasarkan penelitian mengenai budaya penghuni gua yang pernah dilakukan selama ini, menurut Simanjuntak (1996) dikelompokkan menjadi beberapa budaya yang meliputi budaya serpih bilah, budaya hoabinhian, budaya lukisan dinding gua, dan budaya Sampung. Semua budaya tersebut, menyebar dalam batas ruang yang berbedabeda. Budaya serpih bilah yang secara teknologis merupakan lanjutan dari teknologi 
paleolitik, persebarannya merata di seluruh kepulauan Indonesia dengan inovasi produk lokal yang khas pada masing-masing tempat. Mata panah dengan dasar cekung berkembang di Jawa Timur, lancipan bertangkai di Timor, mata panah bergerigi di Sulawesi Selatan, dan bilah memanjang dengan retus bersayap di sepanjang Sungai Nulbaki (Timor Barat). Budaya hoabinhian persebarannya lebih sempit daripada budaya serpih bilah, yaitu mendominasi daerah pesisir timur Sumatera utara dan Aceh, serta beberapa tempat di Jawa (Heekeren, 1972). Pola hidupnya cenderung bergantung pada subsistensi dengan eksploitasi sumberdaya aquatik dan non aquatik. Sementara itu, budaya lukisan dinding gua umumnya menempati Indonesia bagian timur. Budaya ini hingga sekarang belum pernah ditemukan di Jawa dan Sumatera. Sedangkan budaya Sampung mendominasi wilayah Jawa Timur dengan ciri utamanya berupa industri tulang, batu, kulit kerang, dan industri alat-alat serpih.

Berkaitan dengan budaya Sampung yang berkembang di Jawa ini, tampaknya mencakup wilayah di bagian timur saja. Hal tersebut didasarkan adanya kesamaan unsur-unsur budaya yang berkembang pada satuan-satuan perbukitan gamping di Jawa Timur. Dilihat dari satuan geografis perbukitan karst, setidaknya terdapat sebanyaknya tujuh kelompok gua yaitu Gunung Sewu, Gunung Watangan, Sampung, Dander, Tuban, Situbondo, dan Tulungagung. Dalam tulisan ini sesuai dengan data yang diperoleh baik data primer maupun data sekunder akan dikaji empat kelompok gua tersebut di depan (Gunung Sewu, Gunung Watangan, Sampung, dan Dander), sementara tiga kelompok gua tersebut di belakang (Tuban, Situbondo, dan Tulungagung) dalam tulisan ini tidak dibahas. Hal tersebut disebabkan kurangnya data yang diperoleh.

\section{Settlement Mikro}

Kajian skala mikro yang dimaksud di sini didasarkan pada persebaran ruangan dan hubungan antar ruang di dalam satu bangunan. Unsur keruangan dalam hal ini terdiri atas artefak, bahan baku, fitur, tempat sumber bahan baku, dan manusia yang mendayagunakan unsur-unsur tersebut. Dalam suatu kegiatan atau aktivitas manusia yang pernah berlangsung tentunya akan meninggalkan jejak-jejak yang ditinggalkan manusia berupa tanda-tanda fisik dan spatial atau ruang. Untuk itu berdasarkan tandatanda dan jejak-jejak yang ditinggalkan manusia penghuni gua dapat direkonstruksi tentang kegiatan yang berlangsung baik itu kegiatan sehari-hari, mingguan, bulanan, tahunan, ataupun kegiatan yang bersifat tidak ajeg (Haryadi, 1993). Berikut akan diungkapkan tentang tata ruang pada tingkat skala mikro (per gua/ceruk) yang terjadi pada.gua-gua di Gunung Sewu, Gunung Watangan, Sampung, dan Dander.

\section{a. Gua-gua di Gunung Sewu}

Gua-gua kelompok ini telah dilakukan penelitian secara intensif oleh Pusat Penelitian Arkeologi terutama di Song Keplek (Punung, Pacitan) dan Gua Braholo (Rongkop, 
Gunungkidul) (Simanjuntak, 1999). Didasarkan pada hasil penelitian tersebut dapat diketahui mengenai aktivitas yang berlangsung pada setiap gua (skala mikro).

Secara umum gua dan ceruk kelompok ini dimanfaatkan sebagai pusat aktivitas untuk beberapa kegiatan, antara lain untuk lokasi kegiatan industri, lokasi penguburan dan tempat tinggal. Ketiga fungsi ini dapat diamati di Song Keplek. Kegiatan industri ("atèlier") berlangsung di bagian selatan mendekati pintu gua. Sisa kegiatan pembuatan alat-alat batu yang terdiri dari serpihan-serpihan buangan (chunks), serpih dipakai, serpih dipakai diretus, batu inti, dan perkutor tersebar sangat padat, membentuk lapisan setebal $10-15 \mathrm{~cm}$. Di gua Braholo bagian yang mendekati pintu gua (dalam hal ini bagian baratdaya) juga difungsikan untuk "atèlier". Serpihan pangkasan yang merupakan produk buangan (waste product), peralatan yang dihasilkan dan peralatan yang digunakan (perkutor) bertumpuk padat di bagian ini.

Pemanfaatan gua untuk tempat penguburan menunjukkan kecenderungan pada bagian yang lebih terisolasi, di dekat dinding gua. Di Song Keplek lokasi penguburan menempati bagian baratdaya yang memanjang di dekat dinding gua. Sementara itu di Gua Braholo berada di bagian barat mendekati dinding gua. Aktivitas untuk kegiatan sehari-hari, terutama berlangsung pada bagian tengah. Hal tersebut didasarkan banyaknya temuan sisa berbagai jenis binatang buruan, moluska darat, air tawar, dan laut, sisa pembakaran, dan biji-bijian. Keseluruhan temuan tersebut mengisyaratkan adanya berbagai kegiatan yang berlangsung secara teratur dan berkesinambungan di dalam gua dalam jangka waktu lama.

Berdasarkan pemanfaatan lahan gua yang ada pada kelompok gua di kawasan Gunung Sewu, tampaknya pemanfaatan lahan gua/ceruk adalah multi fungsi (sebagai perbengkelan, kuburan, daspur, dan base camp). Secara garis besar dapat dibuat skema bentuk pemanfaatan lahan gua/ceruk pada kelompok Gunung Sewu di bawah ini.

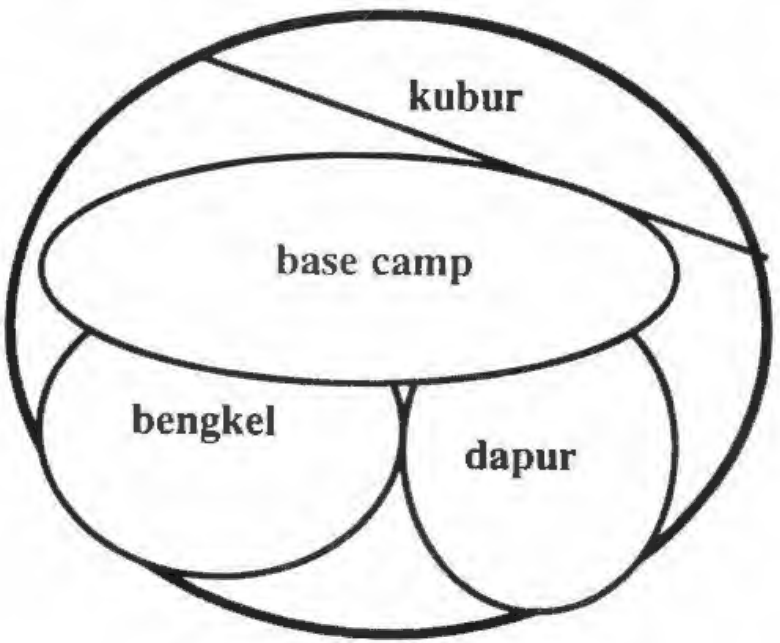

SONG KEPLEK

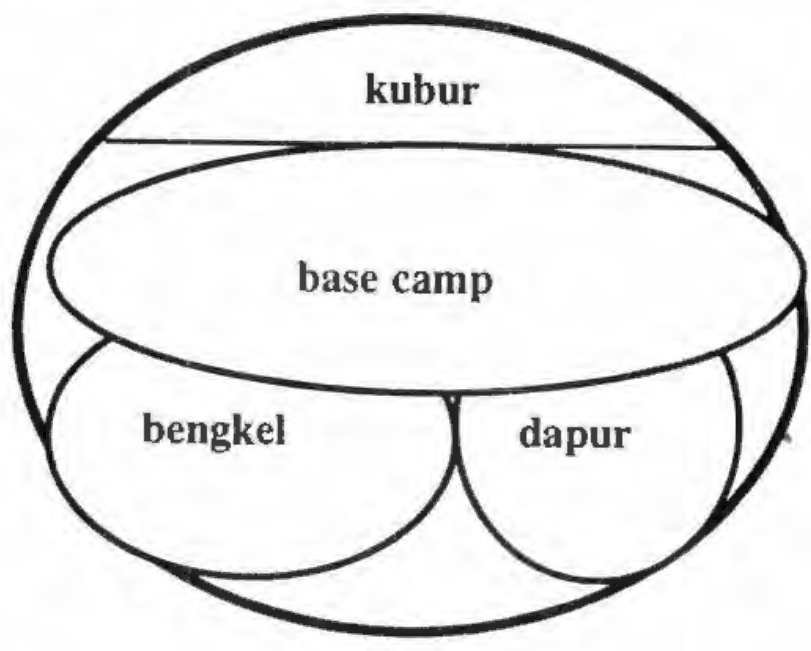

GUA BRAHOLO 
Sketsa di atas menunjukkan bahwa dalam satu unit gua (skala mikro) dapat diketahui pola permukiman yang diterapkan pada gua-gua kawasan Gunung Sewu. Dalam hal ini dapat diartikan bahwa suatu kajian skala mikro akan diketahui secara keseluruhan tingkat budaya yang dikenal dalam komunitas (skala meso) gua ini. Dengan demikian, kajian skala mikro suatu gua/ceruk di kawasan Gunung Sewu mencerminkan tingkat dan perkembangan budaya yang ada secara umum di kawasan ini.

\section{b. Gua-gua di Gunung Watangan}

Penelitian gua-gua dalam kelompok Gunung Watangan pertama kali dilakukan oleh HR van Heekeren di Gua Sodong dan Marjan sejak tahun 1931 sampai dengan 1935. Selanjutnya sejak tahun 1993 sampai dengan 1997 Balai Arkeologi Yogyakarta melakukan penelitian dengan tema Pola Pemanfaatan Lahan Gua pada Komunitas Gunung Watangan yang secara administrasi terletak di Desa Lojejer, Kecamatan Wuluhan, Kabupaten Jember. Penelitian tersebut lebih difokuskan pada gua/ceruk yang belum diteliti oleh peneliti lain seperti Gua Macan dan Gua Gelatik. Selain itu juga dilakukan penelitian ulang pada gua yang sudah diteliti sebelumnya untuk mengetahui lebih dalam pemanfaatan ruangnya.

Berdasarkan pada hasil penelitian di Gua Macan, mikro settlement yang berlangsung menunjukkan pembagian ruangan untuk perbengkelan dan pengolahan makanan biota marin. Kedua aktivitas tersebut didasarkan pada temuan cangkang moluska yang bercampur dengan artefak batu setebal 2 meter lebih. Lahan untuk aktivitas perbengkelan berlangsung pada bagian depan dan tengah. Selain itu aktivitas perbengkelan ini menunjukkan adanya perkembangan dalam pemanfaatannya (secara vertikal). Pada lapisan bawah pemanfaatan aktivitas perbengkelan berlangsung pada lahan bagian dalam atau tengah, sedangkang pada lapisan atas (kedalaman 1 meter dari permukaan tanah) menunjukkan aktivitas berlangsung pada lahan bagian depan. Adapun lahan untuk aktivitas pengolahan makanan biota marin berlangsung pada bagian tengah atau dalam (Nurani, 1998/1999). Melihat posisi temuan antara cangkang moluska dengan artefak batu dalam satu lapisan budaya, diperkirakan terdapat aktivitas utama dan pendukung. Aktivitas utama adalah perbengkelan, sedangkan aktivitas pendukungnya adalah pengolahan bahan makanan dalam hal ini adalah biota marin. Kemungkinan kedua aktivitas tersebut berlangsung pada suatu musim atau waktu tertentu yaitu pada musim basah atau kering. Kondisi tersebut diperkuat dengan keletakan geografis gua ini yang berada pada posisi tertinggi dibanding keletakan gua/ceruk lainnya (lebih lanjut lihat Nurani, 1998).

Pemanfaatan lahan Gua Marjan berdasarkan hasil penelitian van Heekeren (1972) dan selanjutnya penelitian Balai Arkeologi Yogyakarta (Nurani, 1997) menunjukkan gua ini dimanfaatkan sebagai kuburan. Hal tersebut didasarkan pada banyaknya temuan rangka manusia baik utuh maupun fragmental. Selain itu, didasarkan hasil penelitian 
Balai Arkeologi Yogyakarta tampak bahwa pemanfaatan lahan untuk kuburan terletak pada lahan bagian luar sedangkan lahan bagian dalam dimanfaatkan sebagai hunian pada 'masa kemudian (sejarah) (Nurani, 1998/1999).

Berdasarkan hasil penelitian tersebut tampak jelas adanya perbedaan pemanfaatan lahan suatu gua antara komunitas di Gunung Sewu dengan di Gunung Watangan. Gua-gua yang ada dalam komunitas Gunung Watangan menunjukkan masing-masing gua memiliki fungsi sendiri-sendiri untuk kebutuhan komunitasnya. Suatu gua/ceruk difungsikan secara khusus untuk aktivitas tertentu, sehingga gua satu dengan yang lainnya saling berkaitan dan tidak dapat berdiri sendiri karena hanya dimanfaatkan secara tunggal. Hal tersebut dibuktikan dari karakter masing-masing gua yang berbeda dan memiliki fungsi sendiri-sendiri untuk kebutuhan komunitasnya.

Lebih lanjut dapat dibuat suatu sketsa bentuk pemanfaatan lahan gua/ceruk skala mikro yang berlangsung pada kelompok Gunung Watangan.

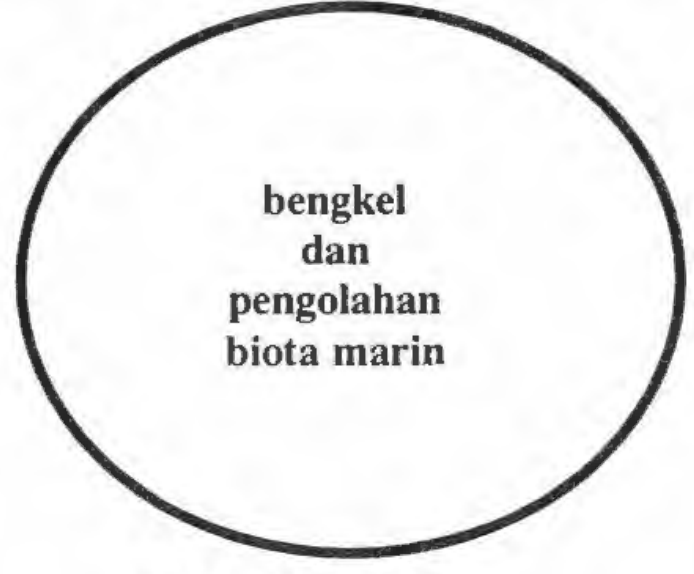

GUA MACAN

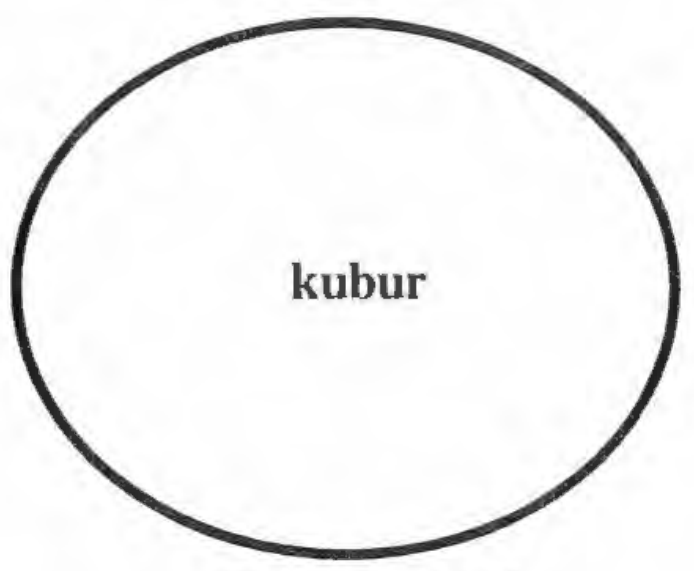

GUA MARJAN

\section{c. Gua-gua di Sampung}

Penelitian gua di daerah Sampung pertama kali dilakukan oleh van Es (seorang geolog) di Gua Lawa. Perhatian LJC van Es diawali pada banyaknya temuan tulangtulang binatang pada Gua Lawa disertai dengan temuan berupa tembikar, alat tulang (terdapat dua macam sudip dan semacam belati dari tanduk), alat cangkang moluska, mata panah bersayap dan berpangkal konveks, serpih bilah sederhana, hematit, perhiasan cangkang moluska, dan rangka manusia posisi terlipat. Berdasarkan temuan tersebut, kemudian secara arkeologis dilakukan penelitian oleh van Stein Callenfels pada tahun 1928 -- 1931. Hasil penelitiannya menunjukkan adanya tiga lapisan budaya (Heekeren, 1972). Lapisan atas ditemukan perunggu-besi, tembikar modern bercampur alat-alat neolitik. Lapisan tengah ditemukan alat-alat tulang dan tanduk yang merupakan temuan terpenting antara lain berupa belati tanduk, lancipan, mata kail, dan sudip tulang ( 99 buah). Lapisan bawah mengandung temuan mata panah, 
sumpitan, tembikar berhias pola tali, batu pipisan, batu giling, serpih bilah sederhana, serut ,cangkang moluska, dan rangka manusia posisi terlipat.

Selanjutnya, Balai Arkeologi Yogyakarta melakukan penelitian pada gua-gua sekitar Gua Lawa yang ada di daerah Sampung yaitu di ceruk Layah, Ngalen, dan Gua Tutup. Sebagaimana diketahui bahwa Gua Lawa memiliki kandungan temuan baik artefak, ekofak, maupun fitur dalam jumlah yang banyak dan bervariasi. Sementara itu hasil ekskavasi pada gua/ceruk sekitar Gua Lawa menunjukkan potensi budaya cenderung homogen seperti yang ditunjukkan pada hasil ekskavasi pada ceruk Layah yaitu berupa artefak batu pada lapisan bawah dan tembikar pada lapisan atas (Nurani, 2000). Hal tersebut menunjukkan bahwa gua/ceruk sekitar Gua Lawa merupakan gua yang dimanfaatkan sebagai aktivitas pendukung dalam pola hidup komunitasnya. Sementara Gua Lawa dimanfaatkan sebagai gua induk dalam aktivitas seluruh komunitas kawasan ini, sehingga kandungan budayanya tampak kompleks dan beragam.

Lebih lanjut dapat dilihat sketsa pemanfaatan lahan gua pada wilayah Sampung sebagai berikut.
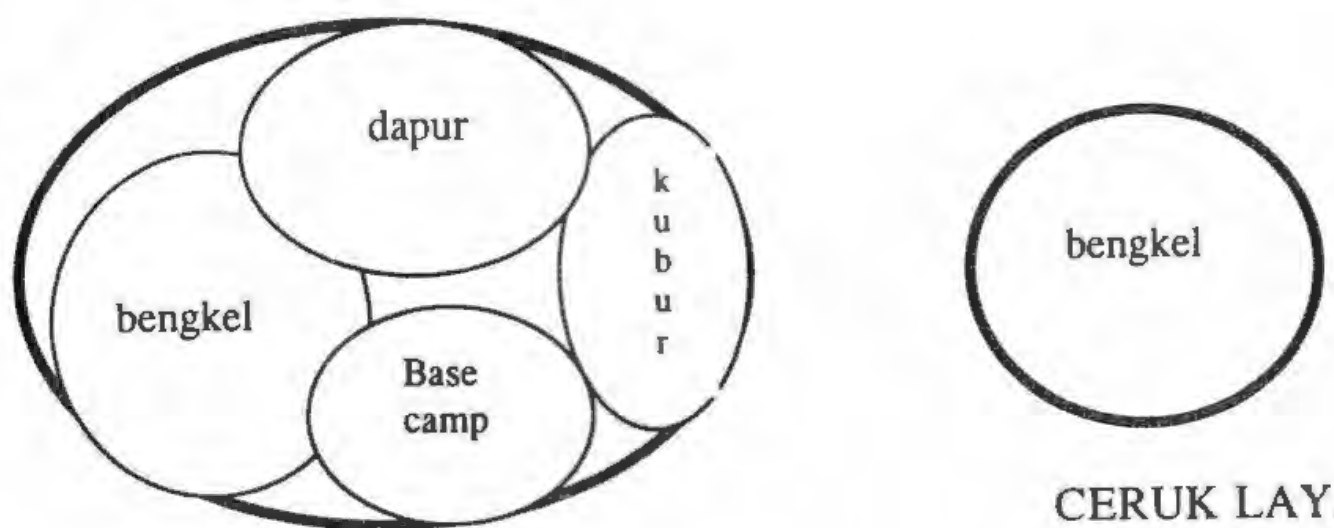

GUA LAWA

CERUK LAYAH

\section{d. Gua-gua di Dander}

Pemanfaatan lahan gua/ceruk skala mikro pada kawasan Bojonegoro (Dander) memiliki karakter tersendiri pula yang berbeda dengan kelompok-kelompok gua di atas. Gua-gua atau ceruk-ceruk yang ada pada kelompok Dander menunjukkan lapisan tipis dengan hasil budaya yang minim. Sejak penelitian pertama kali yang dilakukan oleh LJC van Es pada tahun 1926 di Gua Kramat dan Gua Lawang, menunjukkan bahwa kelompok gua Dander minim hasil budaya dalam lapisan tanah yang tipis. Lapisan tanah sebagian besar merupakan endapan aluvial yang tidak mengandung hasil budaya manusia penghuni gua. 
Berdasarkan hasil penelitian yang telah dilakukan Balai Arkeologi Yogyakarta dan Puslit Arkeologi tampak jelas bahwa gua/ceruk pada kelompok ini minim hasil budaya. Ekskavasi yang telah dilakukan (6 (enam) gua/ceruk) menghasilkan temuan 5 artefak tulang/gigi dan artefak batu berupa serut dan debris masing-masing sebuah (Nurani, 1999a). Melihat jumlah gua/ceruk yang ada pada kelompok ini dibanding temuan artefak (hasil budaya) tampak jelas bahwa kawasan ini minim hasil budaya. Hal tersebut didukung dengan kondisi geografis daerah ini yang sediaannya cenderung homogen baik flora maupun faunanya. Selain itu, lembah yang ada berbentuk $U$, di mana bentuk tersebut memiliki karakter lembab dan tidak nyaman untuk ditempati pada waktu yang lama. Berdasarkan hal itu, kemungkinan guagua/ceruk kelompok ini dimanfaatkan secara khusus atau insidental dan ditempati dalam jangka waktu pendek. Karakter tersebut menyiratkan bahwa gua-gua kelompok ini pemanfaatannya berkaitan dengan kelompok gua lainnya yang memiliki potensi arkeologi (hasil budaya) tinggi dengan kondisi geografis yang subur dengan sediaan flora dan fauna yang bervariasi. Tampaknya kondisi tersebut terdapat di daerah guagua Tuban dan Sampung (Nurani, 1999b). Kedua kelompok tersebut sebagaimana telah diuraikan pada bagian c memiliki potensi arkeologis dengan kondisi geografis yang memadai untuk hunian pada jangka waktu panjang dan lama yaitu lembah bentuk $\mathrm{V}$ dengan sediaan sumberdaya alam (sumber makanan dan sumber bahan) yang bervariasi. Sehingga berdasarkan hal tersebut tampaknya gua/ceruk kelompok Dander merupakan daerah transit atau persinggahan perjalanan komunitas dari Sampung ke Tuban atau sebaliknya.

\section{Settlement Semi Mikro (Meso)}

Sebagaimana telah dijelaskan pada awal tulisan ini bahwa tingkatan aktivitas yang lebih besar dari skala mikro adalah skala semi mikro atau komunitas. Berdasarkan pada kajian beberapa gua secara mikro settlement di atas, tampak terdapat beberapa bentuk pemanfaatan lahan gua berkaitan dengan pengaturan ruang atau lahan gua yang tersedia untuk aktivitas penghuninya. Berikut akan diamati pengaturan ruang skala komunitas pada masing-masing kelompok gua di kawasan timur Jawa.

\section{a. Pola Komunitas Gua Kelompok Gunung Sewu}

Berdasarkan uraian skala mikro kelompok gua Gunung Sewu di atas tampak ada beberapa hal yang dapat disimpulkan yaitu sebagai berikut (Simanjuntak, 1996).

- Pemanfaatan gua dan ceruk sebagai ruang multi fungsi (hunian, pusat kegiatan industri, penguburan).

Pemanfaatan sumberdaya batuan, terutama "rijang" untuk mengembangkan teknologi litik yang diwujudkan dalam bentuk industri pembuatan alat-alat yang didominasi alat serpih. 
- Pemanfaatan sumberdaya fauna sebagai bahan makanan dan yang terpenting sebagai industri pembuatan alat-alat tulang dan cangkang moluska (termasuk perhiasan).

- Subsistensi yang didasarkan pada perburuan binatang di sekitar hunian dan pemanfaatan biota marin.

Dalam pola hidup demikian, dapat diasumsikan adanya kehidupan pada masingmasing gua sebagai tempat aktivitas menyeluruh dan kompleks. Ini berarti dalam tingkat keruangan skala meso (semi mikro) terdiri atas beberapa gua yang dihuni dengan berbagai aktivitas yang berlangsung baik sebagai kegiatan perbengkelan, dapur, dan kuburan. Berikut dapat digambarkan pola komunitas yang berlangsung pada himpunan gua di Gunung Sewu.

\section{POLA KOMUNITAS GUA KELOMPOK GUNUNG SEWU}

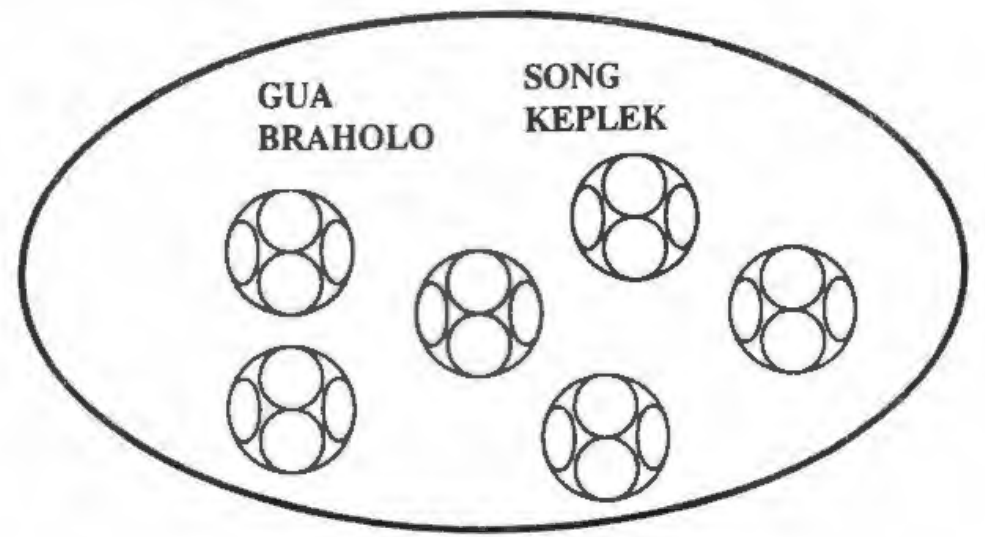

\section{b. Pola Komunitas Gua Kelompok Gunung Watangan}

Berbeda halnya pola komunitas yang berlangsung pada Gunung Watangan. Berdasarkan hasil penelitian yang telah dilakukan Balai Arkeologi Yogyakarta pada gua-gua di Gunung Watangan dapat dijabarkan sebagai berikut (Nurani, 1995).

- Pola mikro (sampel Gua Macan) menunjukkan adanya pembagian tata ruang gua dalam pemanfaatannya. Pada ruang depan didominasi oleh industri litik, sedangkan lahan bagian tengah menunjukkan fungsi pengolahan makanan.

- Masing-masing gua memiliki karakteristik tertentu sehubungan dengan kebutuhan komunitasnya. Hal tersebut didasarkan pada kandungan temuan pada masingmasing gua yang mencerminkan suatu fungsi dan karakter tersendiri. Gua Sodong dengan kandungan temuan yang menonjol berupa industri alat tulang Sampung. Gua Marjan lebih cenderung difungsikan sebagai kuburan dengan kandungan temuan yang didominasi rangka-rangka manusia baik fragmen maupun utuh dari beberapa individu. Gua Macan cenderung didominasi temuan berupa sampah 
dapur (lapisan cangkang moluska) dan industri litik baik masif maupun non masif. Sedangkan Gua Gelatik cenderung dengan temuan industri litik (perbengkelan).

- Indústri litik yang ada pada komunitas ini menunjukkan adanya pengenalan teknologi yang tinggi. Hal tersebut didasarkan pada produk industri yang relatif bagus dengan bahan batuan gamping silikaan rendah, sehingga kualitas batuannya mudah rapuh. Bahan yang mudah rapuh tersebut mampu dihasilkan alat-alat batu yang relatif sempurna. Ini membuktikan bahwa para artisannya sangat piawai.

- Pengolahan makanan molusca pada penghuni gua-gua komunitas ini menunjukkan adanya frekuensi mengkonsumsi yang terpolakan. Diduga adanya penjadualan mengkonsumsinya pada musim-musim tertentu. Selain dimanfaatkan sebagai konsumsi penghuni gua, cangkang molusca dimanfaatkan juga sebagai alat dan perhiasan.

Berdasarkan asumsi tersebut dan dengan melihat potensi temuan yang ada pada komunitas gua di Gunung Watangan, maka gua-gua di Gunung Watangan tersebut dapat digolongkan pada pola komunitas yang terdiri dari gua-gua yang difungsikan sebagai aktivitas tunggal untuk kebutuhan satu komunitasnya. Hal tersebut dapat dijabarkan sebagai berikut. Gua Marjan yang telah diteliti oleh van Heekeren dan diteliti kembali oleh Balai Arkeologi Yogyakarta mempertegas interpretasi van Heekeren yaitu sebagai gua kuburan. Gua Sodong yang juga telah diteliti oleh van Heekeren menunjukkan adanya indikasi gua hunian dengan aktivitas yang berlangsung pada gua ini berupa pengolahan makanan binatang buruan dan perbengkelan. Aktivitas perbengkelan dibuktikan dengan kandungan temuan yang didominasi alat-alat dari bahan batu, tulang, dan cangkang moluska. Sedangkan aktivitas pengolahan makanan binatang hasil buruan dibuktikan dengan ditemukannya fragmen tulang binatang vertebrata dan cangkang moluska sebagai sisa makanan penghuni gua. Adapun Gua Macan dimanfaatkan sebagai gua hunian dengan aktivitas yang berlangsung pada gua ini berupa perbengkelan dan pengolahan makanan biota marin. Sedangkan Gua Gelatik dengan kandungan temuan berupa alat-alat batu masif dan non masif menunjukkan bahwa fungsi gua ini adalah untuk perbengkelan.

Pola komunitas Gunung Watangan yang terdiri atas gua dengan fungsi sendiri-sendiri untuk kebutuhan komunitasnya tersebut tampak jelas adanya keterkaitan fungsi dan keberadaan masing-masing gua. Dengan kata lain masing-masing gua tidak dapat berdiri sendiri. Gua Marjan sebagai gua kuburan tidak dapat berdiri sendiri tanpa melibatkan fungsi dari gua lainnya dalam penjabaran suatu permukiman yang pernah berlangsung pada komunitas gua ini. Demikian pula Gua Macan yang difungsikan sebagai gua untuk aktivitas perbengkelan dan pengolahan makanan biota marin juga tidak dapat berdiri sendiri tanpa melibatkan fungsi gua lainnya. Dengan demikian, pemukiman skala mikro pada komunitas gua ini tidak dapat ditarik suatu interpretasi mengenai pola komunitas yang berlangsung hanya dengan mengandalkan satu gua saja. Sehingga secara tegas dapat diinterpretasikan bahwa pola komunitas gua Gunung 
Watangan ini merupakan suatu sistem setting, dimana aktivitas yang berlangsung pada masing-masing gua tidak dapat dipisahkan secara sendiri-sendiri. Hal tersebut disebabkan karena fungsi masing-masing gua saling mengkait satu sama lain dalam pola komunitasnya.

Lebih lanjut gambaran pola komunitas yang berlangsung pada himpunan gua di Gunung Watangan, dapat dilihat pada skema di bawah ini.

\section{POLA KOMUNITAS GUA KELOMPOK GUNUNG WATANGAN}

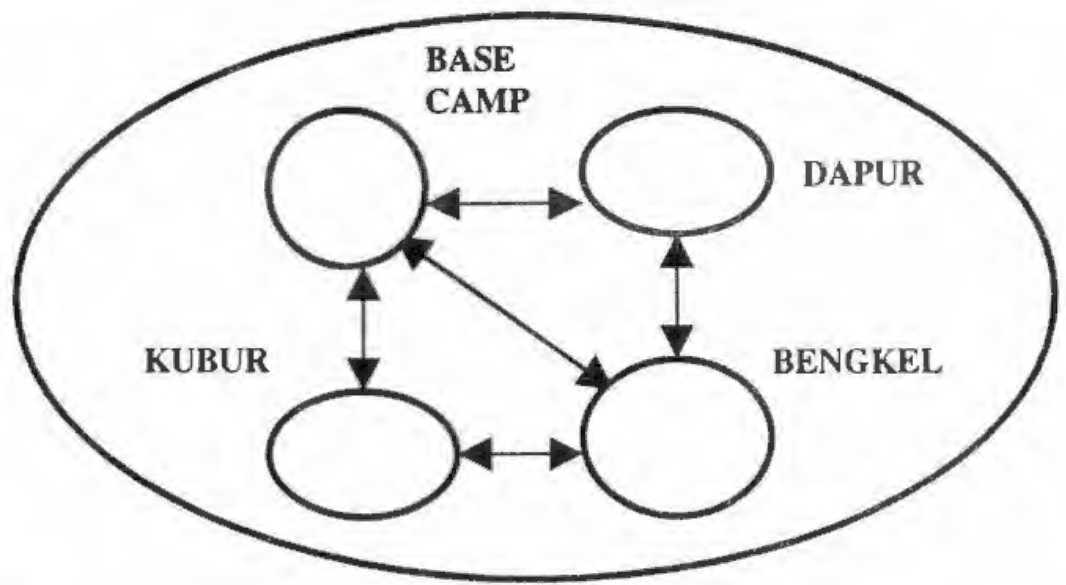

\section{c. Pola Komunitas Gua Kelompok Sampung}

Pola komunitas gua yang berlangsung di Sampung berbeda dengan yang ada pada kedua komunitas di atas. Pada bagian mikro settlement telah diuraikan bahwa pemanfaatan lahan gua antara Gua Lawa dengan Ceruk Layah menunjukkan perbedaan yang menyolok. Tampaknya Gua Lawa pada komunitas ini dimanfaatkan sebagai gua induk, di mana seluruh aktivitas komunitas berlangsung. Sementara itu Ceruk Layah dimanfaatkan untuk aktivitas pendukung. Hal tersebut didasarkan pada perbandingan hasil ekskavasi antara Gua Lawa dengan Ceruk Layah. Temuan artefak, ekofak dan fitur pada Gua Lawa lebih bervariasi baik kualitas maupun kuantitasnya dibanding Ceruk Layah. Selain itu, berdasarkan temuan artefak pada Ceruk Layah menunjukkan adanya perkembangan pemanfaatan ceruk. Pada awalnya (lapisan bawah) Ceruk Layah dimanfaatkan sebagai perbengkelan alat batu, selanjutnya pada masa kemudian (lapisan atas) didominasi temuan tembikar. Sementara temuan ekofak pada Ceruk Layah cenderung minim. Hal tersebut dapat disimpulkan bahwa pola komunitas gua di Sampung terdiri atas gua induk dengan kompleksitas budaya yang berlangsung dan gua/ceruk pendukung yang dimanfaatkan untuk aktivitas sekunder.

Lebih lanjut dapat dilihat skema pola komunitas gua yang berlangsung di Sampung, seperti di bawah ini. 


\section{POLA KOMUNITAS GUA KELOMPOK SAMPUNG}

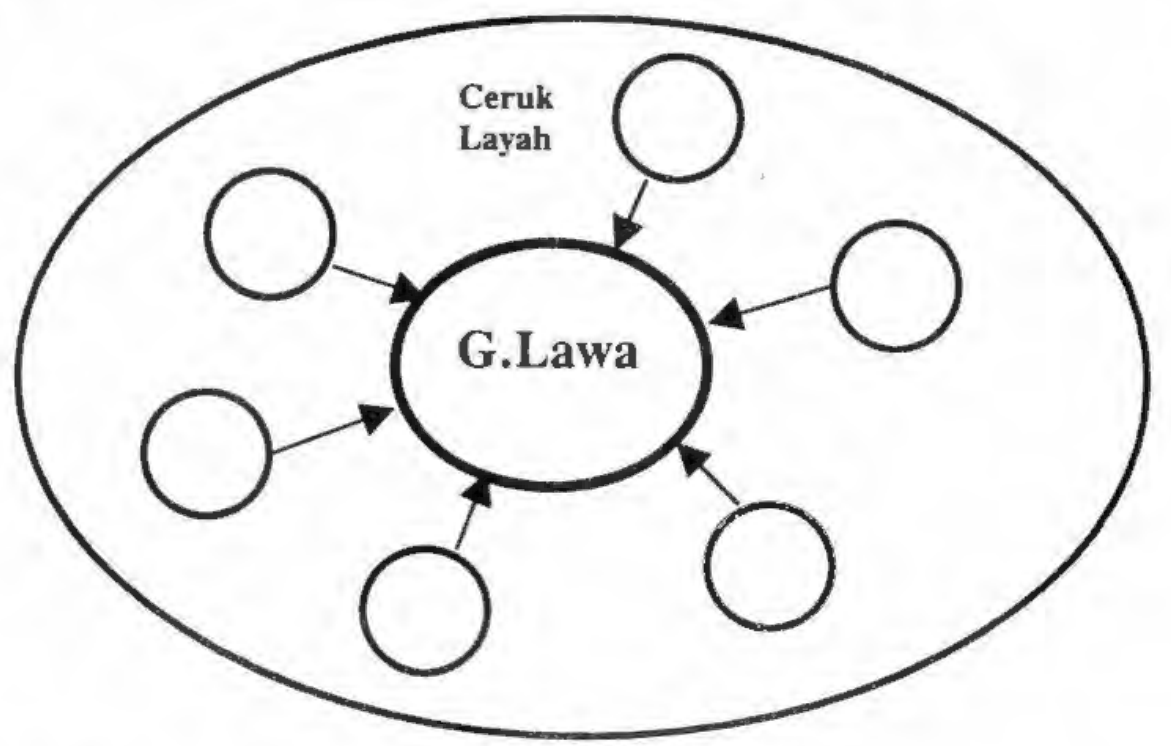

\section{d. Pola Komunitas Gua Kelompok Dander}

Selanjutnya berdasarkan penelitian yang telah dilakukan terhadap himpunan gua di Kecamatan Dander, menunjukkan adanya pola komunitas yang berbeda dari komunitas gua lainnya. Sebagaimana telah diuraikan pada bagian mikro settlement, kelompok gua di Dander ini minim hasil budaya dengan kondisi lembah bentuk U dan sediaan sumber bahan makanan homogen. Berdasarkan kondisi tersebut, tampaknya gua-gua di Dander hanya dimanfaatkan sebagai tempat persinggahan (insidental) oleh manusia dalam mencari daerah yang memenuhi kebutuhan hidupnya. Hal tersebut didasarkan pada keletakan gua-gua di Dander yang berada di antara himpunan gua di Sampung (selatan) dan Tuban (utara). Selain itu berdasarkan potensi arkeologis (data artefaktual) baik secara kualitas maupun kuantitas menunjukkan kedua daerah tersebut sangat tinggi dan bervariasi dibandingkan potensi arkeologis pada gua-gua di Dander yang sangat minim dan tidak didukung dengan lapisan budaya.

Kondisi geografis dan potensi arkeologis gua-gua di Dander tersebut menunjukkan bahwa kelompok gua ini sangat minim baik dari segi budaya maupun potensi ekologisnya. Hal tersebut dapat diasumsikan bahwa kelompok gua Dander bukanlah merupakan komunitas yang mandiri. Dengan kata lain himpunan gua di Dander bukanlah merupakan komunitas yang berlangsung dengan sediaan alam untuk pemenuhan kebutuhan hidupnya yang mencukupi, namun sangat bergantung pada komunitas lainnya. Kemungkinan himpunan gua di Dander merupakan daerah transit dalam perjalanan dari Sampung ke Tuban atau sebaliknya. Untuk mengetahui kepastian dugaan tersebut perlu diteliti lebih mendalam antara kedua himpunan gua (Sampung dan Tuban) lainnya, sehingga akan dapat direkonstruksi bagaimana hubungan ketiga komunitas gua tersebut berlangsung. 
Berdasarkan dugaan tersebut di atas, permasalahan mendasar yang perlu dipecahkan adalah mengapa dalam suatu komunitas yang sangat minim budayanya dengan kondisi geografis yang homogen, berkembang di antara komunitas-komunitas gua yang potensial budayanya dengan kondisi geografis yang bervariasi?. Terlepas dari dugaan tersebut, sebagai gambaran pola komunitas gua di Dander adalah sebagai berikut.

SAMPUNG

DANDER

TUBAN

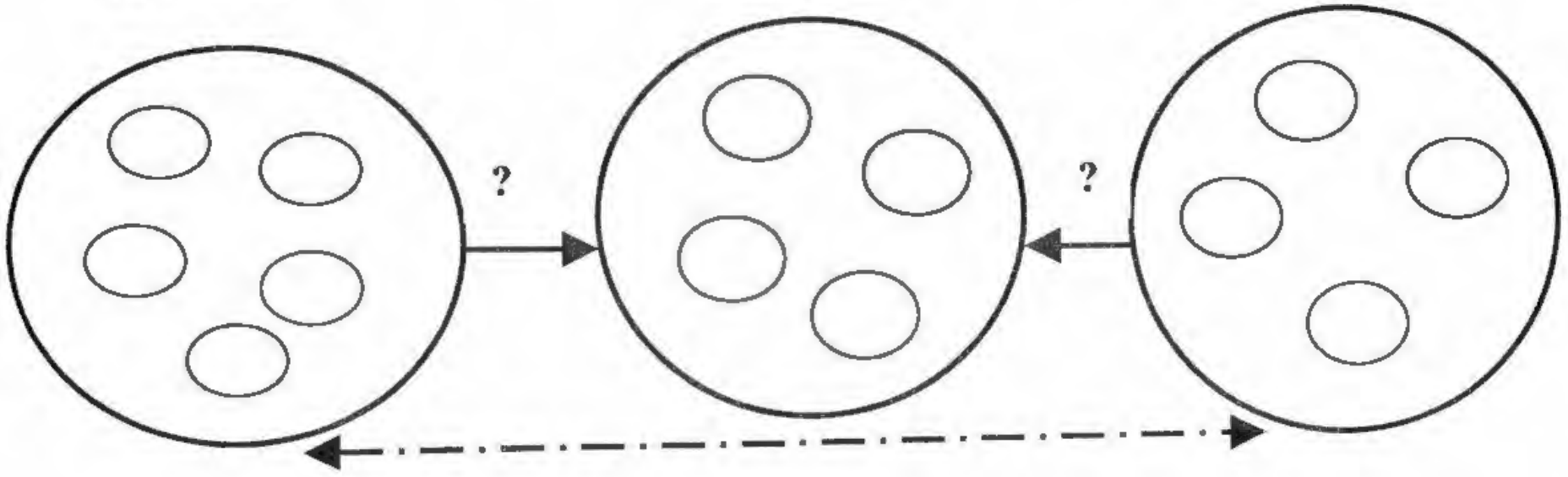

C. Penutup

Dari uraian tersebut di atas, dapat disimpulkan hal-hal sebagai berikut.

$>$ Mikro settlement masing-masing gua di kawasan timur Jawa menunjukkan adanya 5 bentuk pemanfaatan yaitu sebagai berikut.

1. Gua/ceruk dimanfaatkan sebagai ruang multi fungsi yaitu sebagai tempat untuk kegiatan sehari-hari, perbengkelan, pengolahan makanan (dapur), sekaligus sebagai kuburan.

2. Gua/ceruk dimanfaatkan sebagai tempat untuk aktivitas tunggal yang dimanfaatkan seluruh komunitasnya, seperti gua/ceruk untuk dapur umum, gua/ceruk untuk perbengkelan, gua/ceruk untuk kuburan, atau gua/ceruk sebagai base camp.

3. Gua/ceruk dimanfaatkan sebagai gua induk atau pusat aktivitas dalam suatu komunitas, sehingga dalam gua induk ini terdapat berbagai aktivitas yang berlangsung dalam komunitasnya.

4. Gua/ceruk dimanfaatkan sebagai ruang aktivitas pendukung yang bersifat sekunder dalam suatu komunitas.

5. Gua/ceruk dimanfaatkan sebagai tempat untuk transit yang bersifat insidental. 
$>$ Community layout atau pola komunitas gua-gua hunian di kawasan timur Jawa terdiri atas empat pola, yaitu sebagai berikut.

1. Pola komunitas yang terdiri atas gua-gua yang dimanfaatkan secara multifungsi. Dengan demikian suatu gua dalam komunitas seperti ini mencerminkan tingkat budaya yang ada dalam komunitasnya. Pola komunitas ini terjadi pada kelompok gua Gunung Sewu.

2. Pola komunitas terdiri atas gua/ceruk yang dimanfaatkan sebagai tempat aktivitas tunggal untuk kebutuhan seluruh komunitanya. Dalam hal ini terdapat gua/ceruk sebagai dapur umum, perbengkelan, atau sebagai kuburan. Dengan demikian antara gua/ceruk satu dengan yang lainnya saling berkaitan dan tidak dapat dipisahkan dalam aktivitas komunitasnya. Kondisi pola demikian terjadi pada kelompok gua Gunung Watangan.

3. Pola komunitas terdiri atas gua yang dimanfaatkan sebagai pusat aktivitas seluruh komunitasnya yang dikelilingi oleh gua/ceruk yang dimanfaatkan sebagai aktivitas sekunder atau pendukung. Dalam hal ini dapat dilihat pada kelompok gua Sampung, di mana Gua Lawa sebagai pusat aktivitas baik aktivitas perbengkelan, dapur, kuburan ataupun base camp, sedangkan Ceruk Layah dimanfaatkan sebagai aktivitas pendukung yaitu perbengkelan.

4. Pola komunitas terdiri atas gua/ceruk yang dirnanfaatkan secara insidental dengan ciri minimnya hasil budaya. Selain itu, kondisi geografis merupakan lembah bentuk $U$ dengan vegetasi homogen. Dengan demikian pola komunitas seperti ini bukan merupakan komunitas yang mandiri, namun bergantung pada komunitas lainnya yang berada di sekitarnya. Kondisi kelompok gua dengan pemanfaatan secara insidental, kemungkinan dimanfaatkan sebagai tempat singgah dikarenakan jarak antara daerah asal dengan daerah tujuan terlampau jauh. Pola komunitas seperti ini terjadi pada kelompok gua di Dander, Bojonegoro.

Berdasarkan kesimpulan di atas, tampaknya perlu dikaji lebih lanjut pada masingmasing komunitas mengenai kronologi dan pertanggalan hunian yang berlangsung. Hal tersebut penting dilakukan dalam kaitannya dengan kajian pola zonal (skala makro) yang terjadi pada situs-situs gua kawasan timur Jawa. Selain itu melihat potensi arkeologis dengan kondisi geografis yang ada pada masing-masing kelompok gua, tampaknya menarik untuk dirunut lebih lanjut hubungan antar kelompok dalam pola hidupnya, sehingga akan dapat direkonstruksi pola hidup manusia penghuni gua kawasan timur Jawa secara menyeluruh. 


\section{KEPUSTAKAAN}

Clarke, David L., 1977. Spatial Archaeology. London: Academic Press.

Haryadi, nfn. (1995). Kemungkinan Penerapan Konsep Sistem Seting Dalam Penemukenalan Penataan Ruang Kawasan. Berkala Arkeologi, 15(3), 5-9. https://doi.org/10.30883/jba.v15i3.664

Heekeren, HR van.1972. Stone Age of Indonesia, VKI, The Hague : Martinus Nijhoff.

Mundardjito, 1985. Manfaat Studi Pemukiman Bagi Disiplin Ilmu Arkeologi, Diskusi Ilmiah Arkeologi VI, Jakarta : 1AAI Komisariat Daerah DKI Jakarta dan Jawa Barat.

Nurani, I. A. (1995). Pola Permukiman Gua-Gua Di Kaki Gunung Watangan: Suatu Hipotesis Permukiman Gua Kawasan Timur Jawa. Berkala Arkeologi, 15(3), 78-86. https:// doi.org/10.30883/jba.v15i3.676

Nurani, Indah Asikin, 1997. Laporan Hasil Penelitian Arkeologi Pola Pemanfaatan Lahan Gua pada Komunitas Gua Gunung Watangan. Tidak diterbitkan.

Nurani, Indah Asikin, 1998. Setting Himpunan Gua Daerah Jember, Evaluasi Hasil Penelitian Arkeologi (EHPA) di Cipayung, Jawa Barat 16 -- 20 Februari, belum terbit.

Nurani, Indah Asikin, 1998/ 1999. Laporan Penelitian Arkeologi (LPA) Pola Pemanfaatan Laban Gua pada Komunitas Gunung Watangan. Belum terbit.

Nurani, Indah Asikin, 1999a. LPA Pola Pemanfaatan Lahan Gua-gua di Kabupaten Bojonegoro. Belum terbit.

Nurani, I. A. (1999). Pola Permukiman Gua Di Pegunungan Kendeng Utara. Berkala Arkeologi, 19(2), 1-13. https://doi.org/10.30883/jba.v19i2.818

Nurani, Indah Asikin, 2000. LPA Pola Pemanfaatan Lahan Gua-gua di Kabupaten Ponorogo Tahap I, belum diterbitkan.

Simanjuntak, Truman, 1996. Akhir Plestosen dan Awai Holosen di Nusantara (Bahasan Tentang Karakter dan Kronologi Budaya), PIA VII, Cipanas, Jawa Barat Jilid 2, hlm. 151 - 170.

Simanjuntak, H. T. (1999). Budaya Awal Holosen Di Gunung Sewu. Berkala Arkeologi, 19(1), 120. https://doi.org/10.30883/jba.v19i1.789 